\section{Santoryn a sprawa architektury nowoczesnej}

Santorini and the modern architecture affair

\section{Streszczenie}

Santoryn to zaskakujące miejsce. Turyści zauroczeni wyspą chcą spędzać tu wakacje. A tymczasem niewiele osób spodziewa nie jest oparta nalady architektury nowoczesnej. W przeciwieństwie do wielu wspaniałych metropolii świata, historia wyspy nymi i trzesieniami ziemi. W tak niebeziecznym geoklimacie powstały niezwykłe budowle, które dzieki wpływowi warunków naturalnych, biedy, stały sie niezwykle nowoczesne i ponadczasowe. Autor rozważa elementy architektury zabudowan wyspy, które prowadza do wyżej wymienionych wniosków. Tu nie znajdzie się architektura modernistyczna ale architektura prosta, racjonalna, nowoczesna i ponadczasowa.

\section{Abstract}

Santorini is a surprising place. Tourists attracted to the island want to spend their holidays here. But people don't expect Id, the history of the island is no based on wars, economic growth or political decisions but on volcanic eruptions and earthquakes. In such dangerous geo-climate, due to the influence of natural conditions and poverty, extraordinary buildings were created. They have become extremely modern and timeless. Author considers the architectural elements of buildings on the island, which lead to the above mentioned conclusions. It is impossible to find here architecture of Modernism but architetecture of simplicity, rationality, modernity and eternity.

Stowa kluczowe: Santoryn, erupcja wulkaniczna, architektura nowoczesna, bialy, Nikos Tsebelis

Keywords: Santorini, volcano eruption, modern architecture, white, Nikos Tsebelis

\section{Wstęp}

Na rozwój architektury w różnych miejscach na świecie wpływ ma dziesiątki czynników. Miejsce, kontekst, historia miejsca, rozwój cywilizacyjny, układ polityczny panujący $\mathrm{w}$ danym miejscu... W ten sposób dotrzeć można do czasów najnowszych by zatrzymać się przy architekturze nowoczesnej. Można zapytać się, czym jest architektura nowoczesna. Czy jest to styl w architekturze, czy podejscie do architektury jako sztuki, rzemiosła. Z jedne dernistyczny, który stać sie moż moda i "Mo jokinś czasie odejść; z drugiej ujzzymy architekture nowoczesna sic ontemporary" - racjonalna nowoczesna, wymyśs "Conkatowa i również ponadczasową

Rozważania nad architekturą racjonalną, nowoczesna i unikatową zawiodły autora na jedną z greckich wysp - Santoryn

\section{Historia}

Niezwykłym miejscem, gdzie odnaleźć można wiele przykładow architektury nowoczesnej są zabudowania na greckiej wyspie Santoryn. Tworzy ona z kilkoma mniejszymi niewielki archipelag.
1. Abstract

Dozens of factors affect the development of architecture Darious places around the world. The site, its contex em of a given pace.. This is how we can arrive in the present and discuss modern architecture. One can ask what is modern architecture? Is it an architectural style or an approach to architecture as an art or a craft? On the one hand, one will see an architectural style-the modern style, which can become a sort of a fashion and away after some time; on the other, one can also observe "contemporary" modern architecture-one that is rational, modern, well-planned, unique and likewise timeless. architecture led him to the Greek island of Santorini.

2. History

The island of Santorini is a remarkable place, where we can find many examples of modern architecture. It form a small archipelago alo g with a number a smaler istets. tory. It is undoubtedly closely tied with the geological structure of the planet. Vulcanological studies have shown the this history has been quite tumultuous. A highly developed The author's deliberations on rational, modern and unique

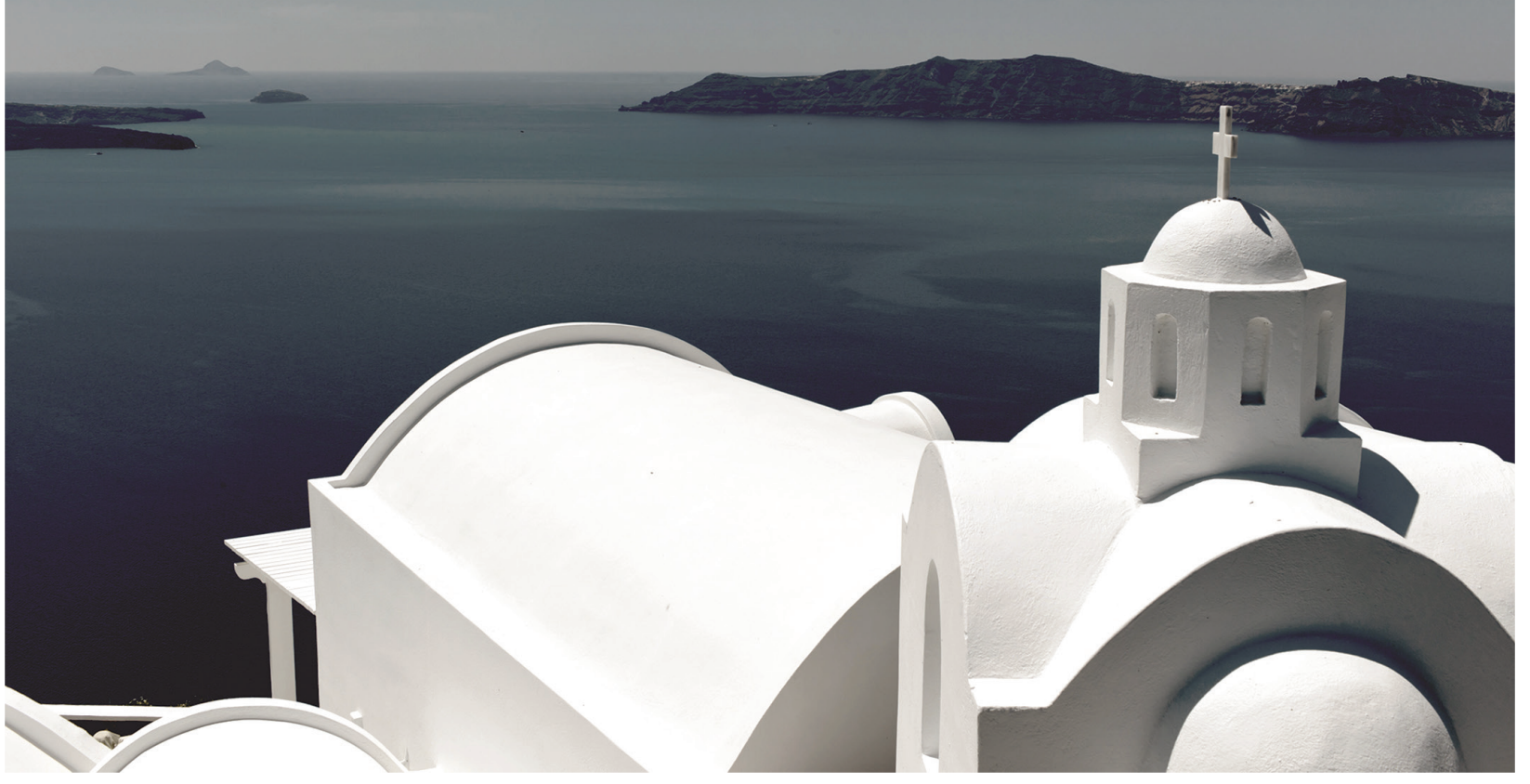

I1. 1. Zabudowa Santorynu, fot. autor / The buildings of Santorini, photo by the author

Warto przyjzzeć się historii wyspy. Niewątpliwie związana jest ona ze struktura geologiczną kuli ziemskiej. Badania wulkanologów wykazują, że była ona niezwykle burzliwa. Już kilka tysięcy lat p.n.e. istniała tu wysoko rozwinietta cywilizacja epoki brązu (kultura minojska). Archeologowie odkryli pozostałości po starozytnym mieście. Santoryn leży na terenie aktywności wulkanicznej. Prawie wszyscy mieszkańcy miasta po kilku poważnych trzęsieniach ziemi zdązyli opuscic wyspę przed głównym kataklizmem. W okolicach 1613 r. p.n.e' potężna erupcja wulkanu zniszczyla zupetnie wyspę. Wyspa jako całos przestała istniećc. Wybuch uwolnif ogromne ilości lawy a komora magmowa zapadła się na głębokosc prawi $400 \mathrm{~m}$. tworząc kalderę. Wywolana w ten sposób fala tsunami zalała oddaloną o ok. $120 \mathrm{~km}$. Kretę powodując poważne osłabienie (jeśli nie upadek) kultury minojskiej. Pył wulkaniczny otoczył całą kulę ziemską. Klimat ochłodzit się na kilka lat. Niektórzy badacze doszukują się związkow tej erupcji z biblijnym eksodusem Izraelitón z Egiptu ${ }^{3}$. Kika lat temu odkryto pod zwalami pumeksu
zasypane miasteczko Akrotiri. Odnaleziono tam pozo-

Bronze Age civilisation (the Minoan culture) emerged here several thousand years ago. Archaeologists discovered the remains of an ancient city here. Santorini is located in an area that displays a high degree of volcanic activity. After a number of major earthquakes, almost all of the island's inhabitants had left it before the main cataclysm arrived. Around $1613 \mathrm{BC1}$, a powerful volcanic eruption destroyed is island completely. The island, as a whole, ceased to ex. Ter collapsed to a depth of almost $400 \mathrm{~m}$ 政 ed the island of Crete, located around $120 \mathrm{~km}$ away, dealing to the Minoan civilisation, all but causing colose, causting a global cooling lasting several years. Some scholars

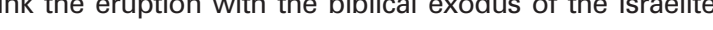
from Egypt3. A couple of years ago, the town of Akroti was discovered, buried under layers of pumice. Remain of buildings, historical monuments, frescoes and elements acts were discovered there.

II. 2. Historia Santorynu związana jest aktywnością wulkaniczna. Na środku kaldery pojawit się wulkan, którego wybuch w XVII w. p.n.e. dopro-

wadzit do upadku kultury minojiskiej fot. autor
III. 2 The history of Santorini is closely tied to volcanic activity. A volcano appeared at the centre of what is now a caldera, its eruption in the se-
venteenth century BC leading to the eventual collapse of the Minoan civilisation, photo by the author

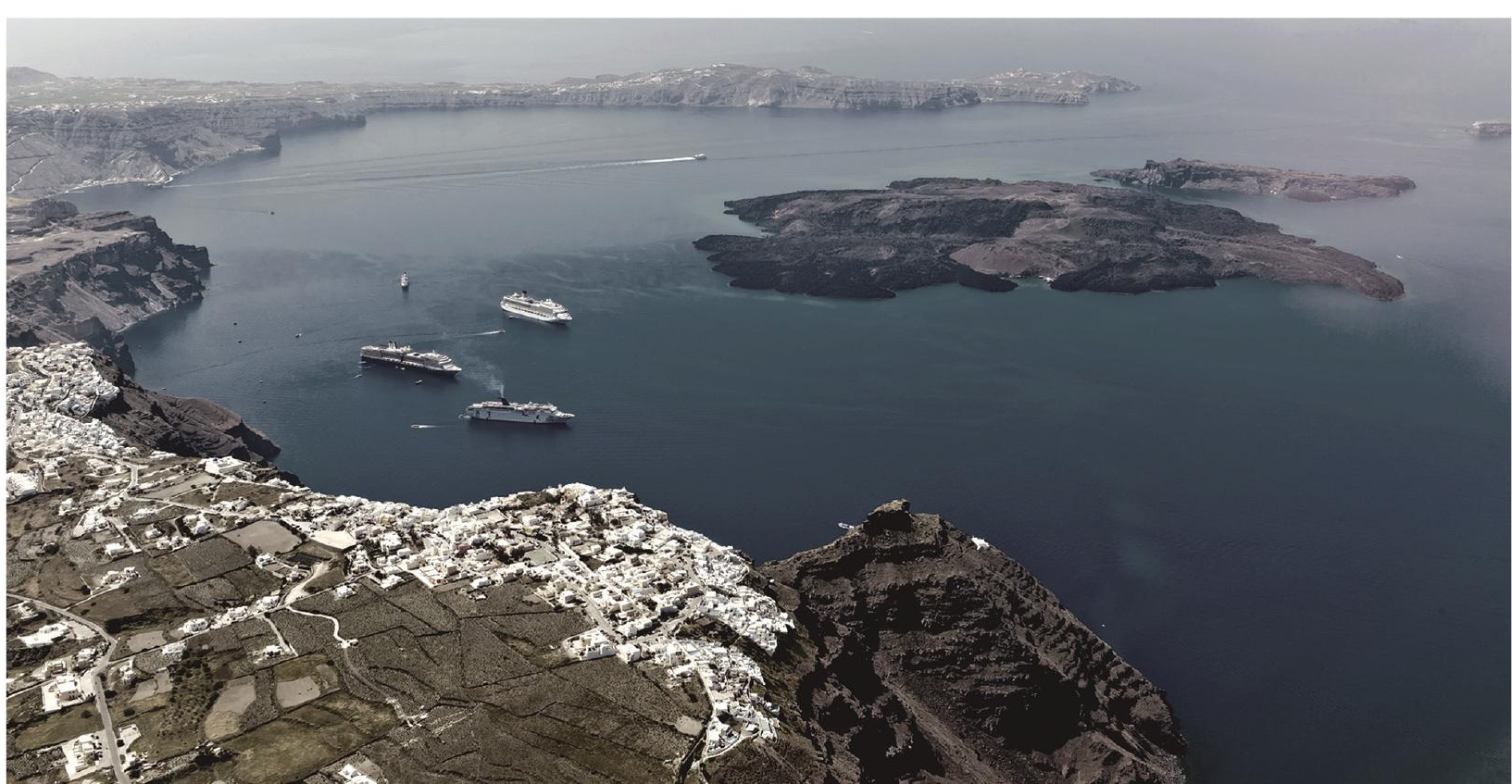



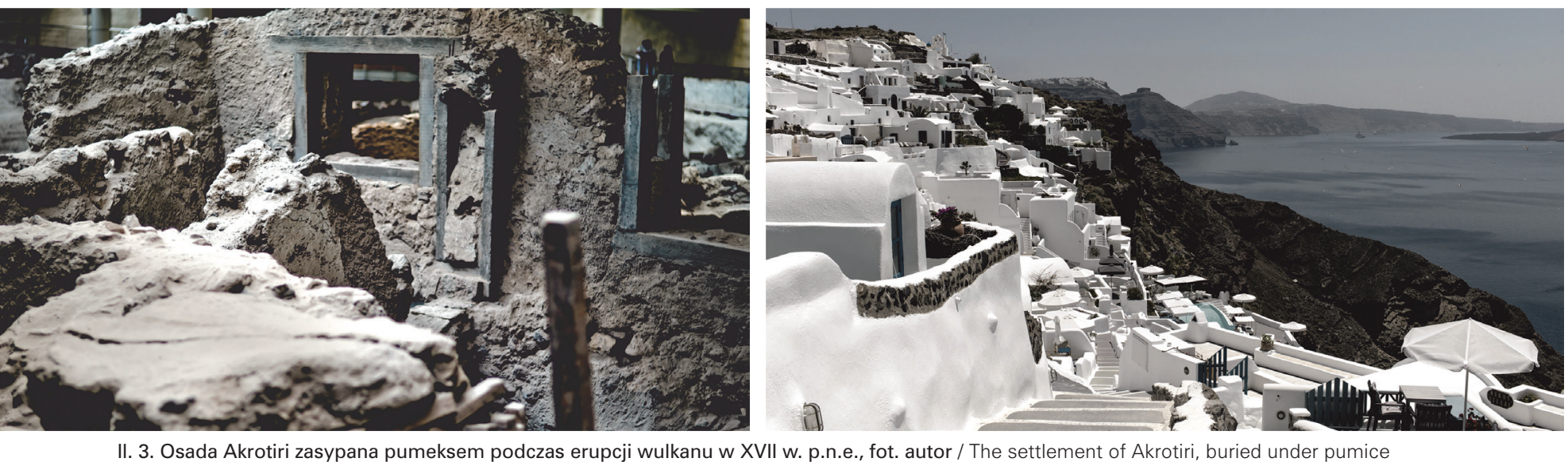

II. 3. Osada Akrotiri zasypana pumeksem podczas erupcji wulkanu w $X V$
during the volcano's erevtuption in the seventeenth century BCE. photo by the
II. 4. Zabudowania Oia, fot. autor / Buildings in Oia, photo by the author

stałości budynków, zabytki, freski, elementy konstrukcji drewnianych domostw $\mathrm{i}$ inne cenne artefakty.

Po tym dramatycznym wydarzeniu, Santoryn był niezamieszkaty przez kolejne 500 lat. Wtedy na wyspe dotarl poczatku naszej ery wulkan dał o sobie znać. Na środpoczątku naszej ery wulkan dał o sobie znac. Na srodku kaldery pojawity się dwie nowe wyspy wulkaniczne
powstałe z wydobywajacej sie magmy - Palea Kamen powstałe z wydobywającej sie magmy - Palea Kamen cje i wyspa sie powieksza. Ostatnia erupcja wulkaniczn miała miejsce w 1950 roku. Obserwujacc architekture Santorynu, zauważyć można,
że wszystkie budynki znajdujące się na archipelagu wokół kaldery nie są starsze niż 60 lat. W 1956 roku trzęsienie ziemi zniszczyło wszystkie zabudowania na wyspie. Wszystkie budowle są nowe. Niektóre zawierają w sobie zabytkowe elementy, ktore pozostały po wybuchu wulkanu i trzęsieniu ziemi.

\section{Architektura}

Obecnie na tej najprawdopodobniej, najpiękniejsze wyspie Grecji rozwija się turystyka. Wiele z istniejącyc budynkow mieszkalnych zamienianych jest na hotele, pensjonaty i wille na wynajem. Buduje się nowe, których podstawową funkcją jest obsługa turystyczna. Nawet mniej popularne miejscowości usytuowane po zachodniej stronie wyspy (bez tak urzekających widoków na kalderę) rozwijają się turystycznie wbrew kiepskim wynikom ekonomicznym samej Grecii

Badacze wierzą, że pierwsze domy Jednym z najpiękpotożona na pótnockym rezydencje, małe cerkwie, waskie, brukowane ścież i biate domy przeplatane z kolorowymi sa przykadem architektury niespotykanej nigdzie indziej: Kontrast biatych domów stojacych na tle czerwono-czarnych klifów powulkanicznych tworzy niezwykłą scenerię.

Z kolei Fira (stolica Santorynu i główne miasto wyspy) również umiejscowiona na klifie znajduje sie naprzeciw wulkanu, który przez ostatnie 2000 lat wyłania sie z mo rza tworząc wyspe Neo Kameni. W tym miasteczku z kolei, można zaobserwować tradycyjne domy z cecham
After this dramatic event, Sanotrini was left uninhabited for the following 500 years, until the arrival of the Greeks. Subsequent centuries passed until the dawn of the next millennium, when the volcano once again made itself known at the start of the Common Era. Two new volcanic islands appeared at the centre of the caldera, ormed from the emerging magma-Palea Kameni and hundred years, expanding the island. The last volcanic eruption took place in 1950

Upon inspection of the architecture of Santorini, we can observe that all of the buildings located on the archAll of its development is new. Some structures feature tion and earthquake.

\section{Architecture}

The island, one of Greece's most beautiful, is currently enjoying a development of tourism. Many of its existing residential buildings are converted into hotels, guest houses and villas for rent. New buildings are built, their island (which do not have as spectacular of a view of the caldera) develop in the direction of tourism desp One of the most beautiful of the island's cliff-side town is Oia, located on the island's northern tip. Its Classica Revival residences, small Orthodox churches and narrow, paved streets and white houses, interspersed with colourul buldings, are examples of an architecture tha white houses and the red and black volcanic cliffs cretes an extraordinary scenery.

Fira (the capital of Santorini and the island's main city), hews been rising from the sea for the past 2000 years whic ing to the formation of the island of $\mathrm{Neo}$ Kameni in the process. Here we can observe traditional houses with elements borrowed from the Venetian style, such as arches, vaulted ceilings and colourful stairs. Due to the difficult pelago's islands are no older than 60 years. In 1956, a earthquake destroyed all of the buildings on the island. main function being catering to the needs of tourists. Even the less-popular towns on the western side of the cannot be found elsewhere. The contrast between the zapożyczonymi ze stylu weneckiego, jak łuki, sklepienia E we sectu na trudne warunki klimatyczne (upal w lecie i mocne huraganowe wiatry w zmie) oraz ochronę przed najazdami pirackini, architektura Firy jest bardzo podobna do innych na Cykladach. Badacze wierzą, ze pierwsze domy mieszkalne zbudowane na zboczach klifów powstawały już w VII wiek n.e. W zalożeniu chronily mieszkanców przez najazdam arabskimi nawiedzającymi rejon Morza Śródziemnego Później w średniowieczu, od XIV wieku powstawały kastelia - zamki warowne w Skaros (obecnie Imerovigli, Aghios Nikolaos (obecnie Oia) i nieco młodsze Pyrgos Emborio, Akrotiri i Panaghia (obecna stolica Fira). Na zboczach w Imerovigli wciąz można zauważyc slady wa-

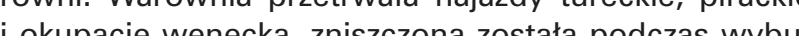
chu pojożone $8 \mathrm{~km}$. na pótnocsy-wách podmorkiego wulknu Kolumbo w 1650 roku ${ }^{4}$. Wszyst kie kastelia zostały porzucone, kiedy mineto zagrożennajazdami pirackimi w potowie XVIII wieku Od togo czasu zaobserwowá można rozwój budowli Santorynu takich jakimi są obecnie.

Wpływ Wenecji jest zauważalny w niektórych zacho wanych ufortyfikowanych osadach, np. Kastro zachoscowości Pyrgos lub zamek wenecki Akrotiri poważnie zniszczony przez Turków otomańskich, pałac Argyros z XIX wieku czy katedra katolicka w Firze

Architektura Santorynu stała się bardziej fantazyjn na poczatku XX wieku, kiedy pod wpływem rolnictwa transportu i handlu mieszkańcy stali się zamożniejsi Podgladano wspaniałe klasyczne rezydencje budowane w całej Europie. W ten sposób powstało na wyspie kilkadziesiąt zwracających uwagę prywatnych pałaców neorenesansowych i neoklasycznych. Zatrudniano wykwalifikowanych robotników, uzzywano drogich materialów. Przy okazil powstaly w podobnym stylu budynki publiczne i kościoły. Dzięki temu, że zbyt wiele tych przykładów nie powstało, ten obcy dla wyspy styl nie zaburza har-

Mieszkańcy wyspy z powodu ograniczonych funduszy, budowali swoje domy korzystając z pomocy okazjona nie zatrudnianych pomocników bez kwalifikacji. Staral się po prostu zbudować dla siebie schronienie nie zwra cając uwagi na estetykę architektury. Można wywnioskować, że panujące czynniki spoleczne, finansowe, klimatyczne, geomorfologiczne przyczynity się do stworzenia tie ningugeego Nauczmy sie zyc

iezmy się żyć w prostocie, jak budować nieprzeciętbe, bez zbędnej ornamentyki, bez gadaniny, zbędnego

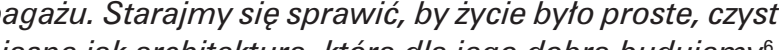
Ten znamienny postulat greckiego architekta XX wieku, uczestnika Ruchu Nowoczesnego znakomicie trafia w ar chitekture Santorini. Wybierajac prehistoryczne Akroti (zbudowane nad morzem, osłonięte przed wiatrami i korzystające z rolnictwa i rybołówstwa) lub domy wkopan $w$ ziemię na zboczach kaldery (yposkafos) w Oia czy Ime rovigli można zauważyć jak architektura zaadaptowała się do warunków klimatycznych panujących na wyspie i do potrzeb mieszkańców na przestrzeni wieków. climate conditions (very hot summers and winters charand the need to fortify settlements against pirate raids, the architecture of Fira is Silar to that of other areas of the Cyclades.

Scholars believe that the first residential buildings to be constructed on the island's cliff sides appeared already in the seventh century CE. They were intended to protect he Mediterranean Aater, during the Middle Ages, speciically from the fourteenth century, kastelia fortified castles-were built in Skaros (present-day Imerovigli) Aghos Nikolaos (present-day Oia) and the slightly younger Pyrgos, Emborio, Akrotiri and Panagia (present-day Fira, the island's capital). On the cliffs in Imeroviglia, we can see the remains of fortifications. The fort survived raids by Turks, pirates and a period of Venetian occupation only to be destroyed in $1650^{4}$ by the eruption of the Kolumbo underwater volcano, which is located $8 \mathrm{~km}$ to the north-east of the island. All of the kastelia were abandoned when the threat of pirate raids disappeared in the middle of the eighteenth century. Since then, we have been able to observe the development of similar buildVentorini.

Venetian influence is clearly observable in some of the of Pyrgos, or the Venetiants, e.g. Kastro in the locality considerably damaged by Ottoman Turks, the Argros palace from the nineteenth century, or the Catholic cathedral in Fira ${ }^{5}$.

The architecture of Santorini became more flamboyan at the start of the twentieth century, when its residents became more affluent thanks to the development of agiculture, transport and trade. They copied magnificen residences they had seen all over Europe. Several dozen eve-catching private Renaissance and Classicist Revivmalaces were built this way. Qualified workers were mployed and expensive materials were used. Public Due to built, their style, alien to the island, failed to disrupt the harmony of its landscape and urban tissue.

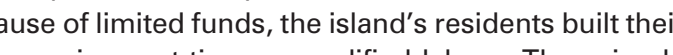
wanted to build shelter for themselves, without rimply for the aesthetic of said shelter's architecture It can be concluded that the social, financial and geo-morphologic conditions prevalent at the time had significantly contributed to the emergence of the island's intriguing architectural style.

Aris Konstantinidis wrote that we should learn to live in simplicity and to build uncommonly, without unnecessary ornament, without excessive complication and baggage. That we should strive for our life to be as simple, pure and bright as the architecture that we build to it

This significant postulate by the Greek twentieth-centu$r y$ architect and a member of the modern movement is highly accurate when it comes to Santorini's architecheltered from wind and benefitting from agriculture and fishing) or the houses dug into the ground on the slopes of the caldera (yposkafos) in Oia or Imeroviglia, we can see how architecture has adapted itself to the island's 


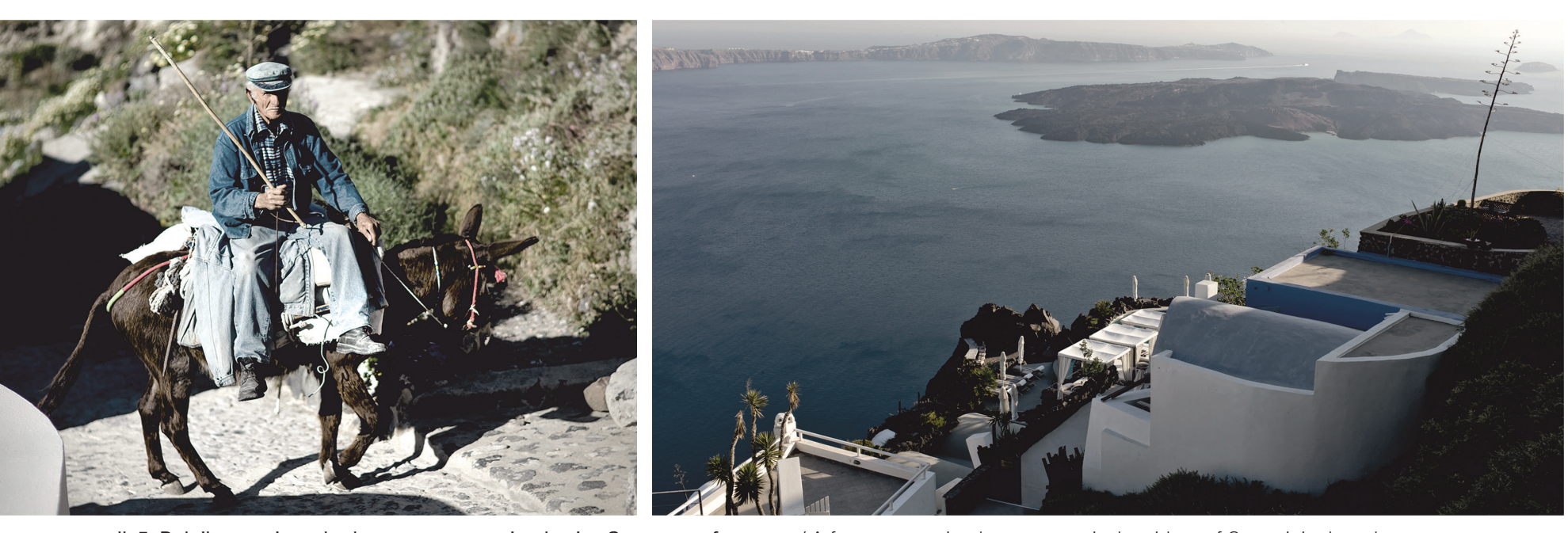

II. 5. Rolnik wracajacy do domu - typowy mieszkaniec Santorynu, fot. autor / A farmer returning home-a typical resident of Santorini, photo by

the author
II. 6. Yposkafos $w$ Firostefani, fot. autor / Yposkafos in Firostefani, photo by the author

Architektura Santorynu zasadzona jest na kulturze ludowej Cyklad. Wyprowadzona jest ze starożytnej filozofil

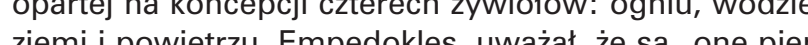
wotne i jakościowo niezmienne"7. Każdy z nich jest zwiazany z lokalnymi cechami środowiskowymi: ogień ze słońcem (i jego promieniowaniem - problem ogrzenania i chłodzenia), woda z wilgotnościa i opadami atmosferycznymi (niewielkie opady deszczu w lecie, wilgoc $\mathrm{w}$ zimie), ziemia z materiałami budowlanymi i powietrze $z$ wiatrem (Santoryn jest narażony na nieustające i intensywne wiatry).

$\mathrm{Na}$ architekture wywiera wpływ historia, krajobraz, klimat, środowisko. Język architektury Cyklad jest harmonijnym zbiorem białych, geometrycznych domów, brukowanych uliczek, wiatraków i niebieskich cerkiewnych koput.

Miasteczka na Santorynie charakteryzują się wysoką ge stością zabudowy, wąskimi uliczkami i małymi budynkami. Ochrona przed wiatrem i upałem od słońca, bezpieczeństwo i stosunki społeczne na wyspie miały wpływ

Płaskie dachy, prostopadłościenne kształty i białe ściany to dominujace cechy lokalnej architektury. Co ciekawe, większość z tutejszych osiedli powstała z prostych ma teriałow w sposobo "niezaprojektowany". Dla mieszkań ców wyspy estetyka nigdy nie stała na pierwszym miej scu. Wystarczylo zapewnić najważniejsze ich potrzeby. Domy najczésciej zorientowane sa w kierunku poludnioralnego światta ściany grubości $60-80 \mathrm{~cm}$. Zapemaja ralnego swilla. Sclany grubosci $z 0-80 \mathrm{~cm}$. Zapewniaja turami. Z drugiej jednak strony, bardzo czesto budyn zagtebiane sa w ziemi (korzystają z dużych spadków od strony stromych brzegów kaldery) chronią wnetrza przed bezpośrednimi promieniami słonecznymi utrzy mujac stała temperature przez cały rok. Niewielkie wysokości, małe powierzchnie użytkowe pomieszczeń we wnątrz budynków ujawniaja problemy i potrzeby życia społeczności Santorynu. Miasteczka wyspy wygladaja tection from the wind and the heat of the sun, as well as the safety and social relationships on the island have contributed to this form of development.

Flat roofs, cuboid shapes and white walls are the dominant characteristics of the local architecture. What is interesting, is that most of the area's settlements have been buitt from simple materials, in an "undesigned" manner. The island's residents never put aesthetics first. They were perfectly happy with satisfying their most essential needs.

The houses are typically oriented towards the south-eas so as to make use the benefits of natural light. Walls typically have a thickness of $60-80 \mathrm{~cm}$. They provide protection against the island's strong winds and high temperatures. On the other hand, buildings are often partially built caldera's edgel protecting their interiors from direct sunlight and maintaining a stable temperature year-round. Small heights and usable floor areas inside the building do come with their problems and lay bare the needs of the community of Santorini. The island's towns appear niemal jak kostki cukru poukładane na szczytach klifów kaldery skąpane w zachodzącym słoncu, wpadającym do morza Egejskiego ${ }^{8}$.

W małych miejscowościach Imerovigli i Firostefani, zaobserwować można niewielkie budynki wkopane częsciowo w ziemię. Pomieszczenia znajdujące się niże stają się dachami i tarasami dla wyzej polożonych pomieszczen. Pomiędzy białymi budynkami ułożonymi kaskadowo znajdują się mate, białe cerkwie z niebieskim kopułami. Pomiędzy zabudowaniami na częściowo wy brukowanych uliczkach zobaczyé można mieszkancoó przemieszczających się po wyspie na swoich osiołkach. Analizując elementy architektury tego miejsca zauważyc można, ż wszystke budynki zaprojektowano w jednobez zd kawe, form nie jest wzieta z przypadku oraz nie pochodzi jelynie z glowy i pomystu projektujace je architekta. Wiekszość budowli ma dach w kształcie prostego wycinka walca Nie ma przekręcé, udziwnień kompozycyjnych. Ale nie wynika to z checi podkreślenia stylu. Kwadratowe lub prostokatne rzuty budowli czasem sie przenikaia. W miejscach przenikania powstaia przejścia do kolejnych pomieszczeń. Dachy w kształcie wycink walca pozwalają na lepsze odprowadzenie goracego powierza z wnętrza pomieszczeń i nie gromadzie sie ono pod stropem. Ściany zewnętrzne budynków sa jednowarstwowe ale maja grubość od 40 do $80 \mathrm{~cm}$. chronia pomieszczenia przed nagrzewaniem wnętrza. Bramy do posesji najczęściej są prostokątne z prostej przyczyny. Najłatwiej się wykonuje a później użytkuje takie wejścia. Wszystkie budynki pomalowane są w kolorze białym by odbijały promienie stoneczne. Obramowania okien i drzwi często malowane są w kolorze ochry co odstrasza owady. Tak budowano rowniez wiele lat wczesniej. Taki sposób myślenia występuje na Santorynie - tu w projekcie liczy się przede wszystkim uzasadnienie i funkcja. Natura jest glównym architektem - klimat, trzesienia ziemi, niedobor materiałow, topografia to pierwsze elementy do analizy, ktore przyszly projekt mus uwzględniać. Tutaj tradycja wynikająca z wieloletniego
doświadczenia dyktuje parametry budynków - od pod-

almost like sugar cubes placed on the tops of the caldera's cliffs, bathed in the sun that sets in the Aegean Sea.

In the small towns of Imerovigli and Firostefani, we can observe small buildings that are partially built underground. The rooms located at a lower elevation provide roofs and terraces to those located higher. Between the white, cascading buildings there are small, white Orthodox churches with blue domes. Between the buildings, idents who move about the island on the backs of their donkeys.

When analysing the elements of the architecture of this Wher, we can observe that all of the buildings were designed in a uniform style. Every building is simple in terms of expression, without ornamentation and has a pure and noble form. What is interesting is that this form is not accidental, nor does it originate solely in the head and from the ideas of their architects. Most of the buildings have arched roofs. There are no twists, no compositional exaggerations. But this is not the result of an intent to highlight a style. The square or rectangle-shaped floor plans of the buildings blend into each other sometimes. Passages to other rooms are formed in those areas. The arched roofs enable the hot internal air to be released so that it does not accumulate underneath the ceiling. External walls have only one layer and have a thickness of between 40 and 80 $\mathrm{cm}$, protecting the interiors from overheating. Gates onto the various properties are rectangular, and for a simple reason. Gates of this type are the simplest to make and sulight Window and door fram ellow colour to repel insects. The same style of building was also used many years prior.

This is the manner of thinking that is prevalent on $\mathrm{San}$ torini-here, designs must be feasible and function above all else. Nature is the primary architect-the climate, earthquakes, a lack of materials and the topography are the first elements that must be analysed in a future design. Here, tradition derived from many years of experience dictates building parameters-from basic assump tions to decorations, with little room for experimentation. Following the words of Tassoula Eptakili, we can systematise Santorini's architecture by assigning it to a number of

11. 7. Zabudowa Oia to przede wszystkim Yposkafos, fot. autor / The buildings of Oia are primarily composed of Yposkafos-type housess, photo
by the author

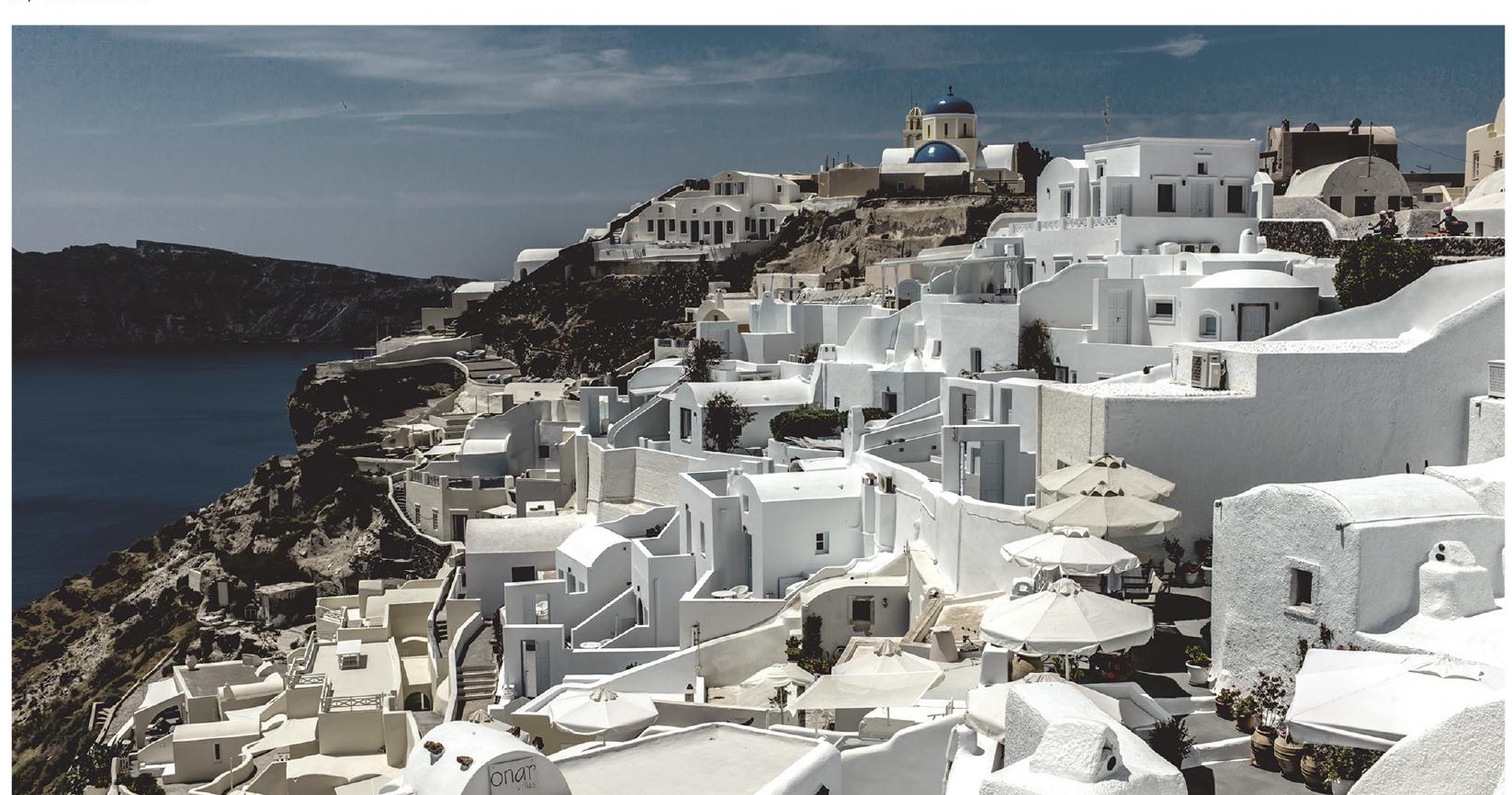




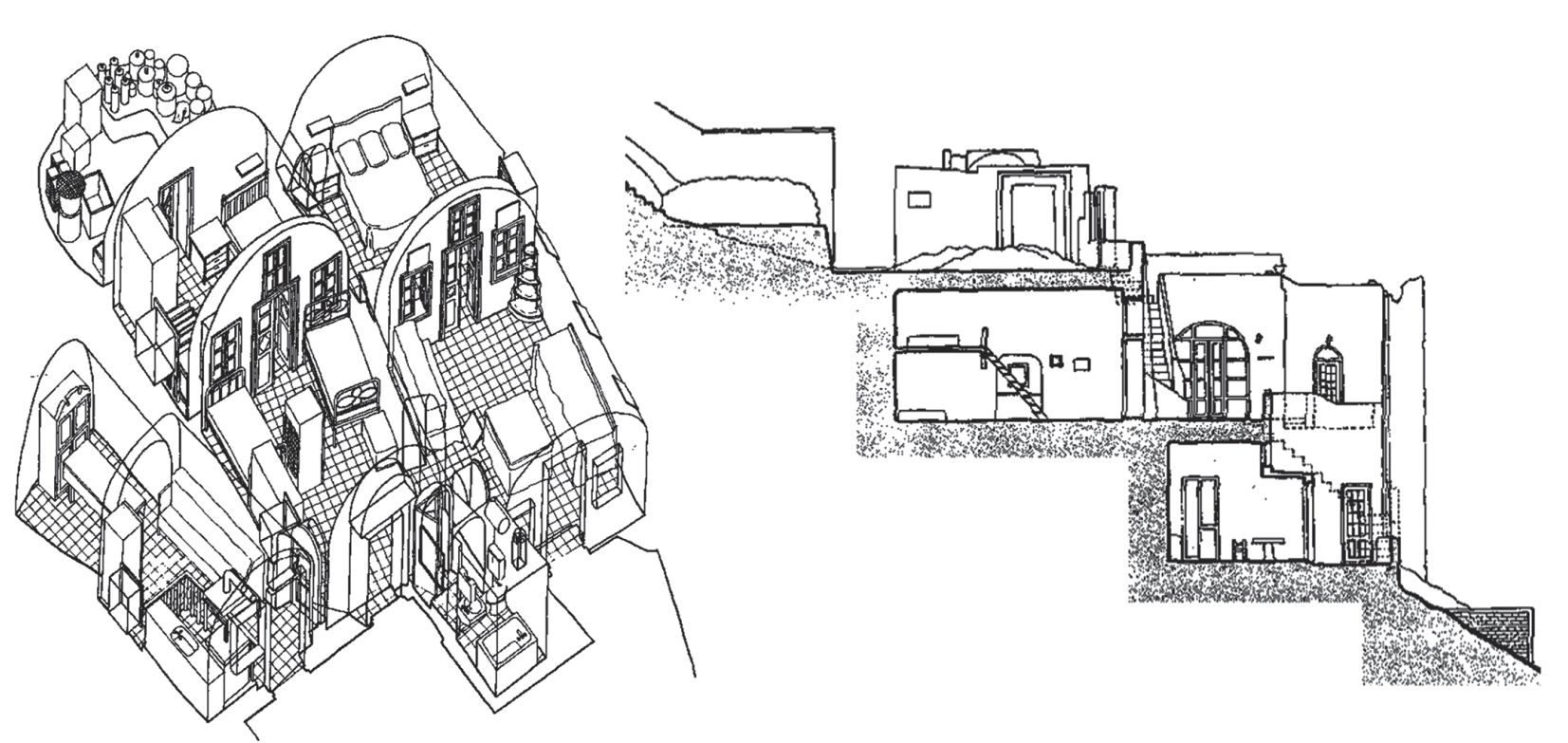

II. 8. Aksonometria i przekrój przez
wing by Thanos N. Stasinopoulos

stawowych założeń do dekoracji z niewielkim miejscem na eksperymentowanie.

Podążając za rozważaniami Tassoula Eptakili, można usystematyzować architekture Santorynu ujmując ją w kilku czytelnych schematach: Kapetanospita, Yposkafos, Agrotospita, cerkwie i niewielkie budynki produkcyjne ${ }^{\text {. }}$

Kapetanospity powstawaly przede wszystkim w miejscowościach Oia i Fira. W tym zamożnym miasteczku, pod koniec XIX wieku, mieszkało 2500 osób, było 13 parafii, bank, urząd celny sporo małych firm produkcyjnych i flota 130 żaglowców. Otoczone było winnicami, z których wino eksportowano do całej Europy. Kapetanospity to budynki duże, często wielopoziomowe, z przestronnymi dziedzińcami, z elementami architektury ludowe ale inspirowane architekturą klasyczną i renesansową Dodatkowo $\mathrm{w}$ architekturę budowli wplatano zbiornik na wode deszczową

Yposkafosy to najpiękniejsze budynki Santorynu. Powstawaly (i powstaja) na skałach wulkanicznych tworząc je sie wzdtuz kaldery w Firze, Oia i Isc z nich zajduja sie rómnizz na ruinach dawnych fortyfikaji Pyrgos, Emborio i Akrotiri W niektórych mieiscowościach, które nie leża przy klifach kaldery równiez buduje sie domy w podobnym stylu korzystajac ze stromszych wznomy i skarp. Najcześciej budowane były przez niezamożnych robotników, rolników i żeglarzy. Budowle najczéscie robotnikow, rolnikow i zeglarzy. Budowle najczęściej wkopane sai w skały w calości, czasem częściowo. Dały lub półłuki. Pomieszczenia są wąskie i głębokie. Od frontu znajduje sie najczéściej pokój dzienny, sypialnie za to najgłtębiej. Niewielkie kuchnie schowane sa za pokojem dziennym. tazienki znalazły swoje miejsca poza głównym budynkiem, zwykle w narożniku tarasu lub dziedzińca. Fronty budynków ustawione są na zachód lub południe natomiast formy budynków podążaja za układem naturalnym kaldery. Dlatego kolejny układ bu- legible schemes: Kapetanospita, Yposkafos, Agrotospita, Orthodox churches and small production buildings 9 . Kapetanospitas were built primarily in the towns of $\mathrm{Oia}$ and Fira. Towards the end of the nineteenth century, this wealthy town was inhabited by close to 2500 people and featured 13 parishes, a bank, a customs office and a substantial amount of manufacturing companies, in addition to a fleet of 130 sailing ships. It was surrounded by vineyards which exported wine all over Europe. Kapetanospitas are large buildings, often featuring multiple levels and spacious courtyards. They are characterised by eleRenaissance-era architecture. Rainwater collection tanks were also incorporated into the architecture ${ }^{10}$.

Yposkafos are Santorini's most beautiful buildings. They were (and still are) built on volcanic rocks, forming entire settlements on the island's cliffs. Most of them are located along the caldera in Fira, Oia and Imerovigli. They can also be found $n$ the ruins of the former fortifications of Pyrgos, Emborio and Akrotiri. In some localities that are not located near the caldera's cliffs, houses are also built in a similar style, utilising some of the steeper hills and escarpments. They were typically built by poor workers, farmers and sailors. These buildings are typically dug into the rock, either partially or in their entirety. The roofs of the surface sections are practically always domes or sections of arches. Interior spaces are narrow and deep. The living room is typically located in the front, while bedrooms are located deeper inside. Small kitchens are hidden behind the living rooms. Bathrooms are located outside of the main building, typically placed in the corners of terraces or courtyards. The fronts of buildings follow the natural layout of the caldera. This is why subsequent rows of buildings are located above the courtyards or terraces of those below them, while the roofs of the buildings below become the floors of those above Another highly interesting element of this architecture

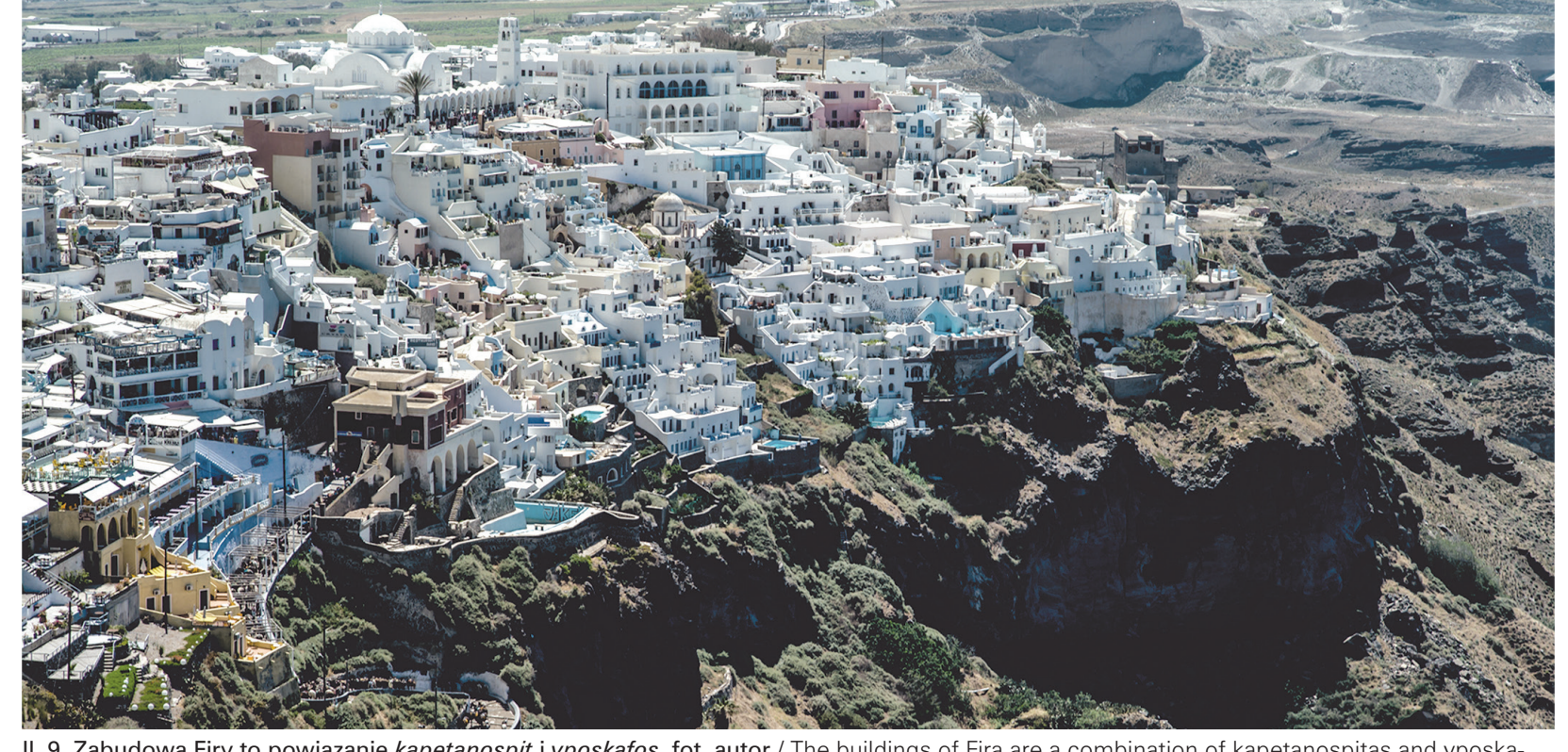

II. 9. Zabudowa Firy to pow
fos, photo by the author

dynków znajduje się nad dziedzińcem lub tarasem poniższego a dachy dolnych zabudowań stają się podłogami górnych'1". Dodatkowym, niezwykle interesującym elementem tej architektury są kopuły, które występuja w rozlicznych kształtach i rozmiarach, podkreślają rzeź
biarskość architektury yposkafos.

4. Wybrane przykłady architektury Santorynu
Jednym z przykładów nowej architektury, nowoczesnej, jest budynek Architect's House projektu Nikosa Tsebelisa z Oikos Architecture ${ }^{2}$.

Budynek został zrealizowany w 1990 roku i był domem rodzinnym architekta przez koline dwadziescia lomem wzieła sie jego nazwa). Wzniesiony zostat na lat (stą jednego z najpiekniejszych klifów na Santorynie z niezwykłym, panoramicznym widokiem na cata kae z Budowla rozłożona jest na jednej kondygnaciji $z$ niewielką antresolą nad jadalnia). Powierzchnia budynku to $145 \mathrm{~m}^{2}$. Znalazły sie w nim pokój dzienny, jadalnia, kuchnia, trzy sypialnie i dwie łazienki.

Projektanta inspirowały natura, ruch i człowiek. Idea projektu było stworzenie budowli w harmonii z natura írodowiskiem poprzez prostotę, rzeźbiarskość i skale. W założeniu projekt tączy tradycyjną, ulotną architekture Santorynu i nowoczesny design. Krawędzie wewnątrz

are its domes, which come in numerous shapes and sizcture of the yposkafos.

4. Selected examples of the architecture of Santorini One example of new, modern architecture of the island is The Architect's House, designed by Nikos Tsebelis from Oikos Architecture'12.

The building was built in 1990 and was the home of the architect for the following twenty years (hence its name). It was built at the top of one of the most beautiful of Santorini's cliffs, with a remarkable, panoramic view of the entire caldera.

The building is laid out on a single level (with a small mezzanine above the dining room). The building's floor area is $145 \mathrm{~m}^{2}$. It includes a living room, a dining room

Its designer was inspired by nature, motion and man. hermen bith nature and the envirome a shructure in plicity, a sculptural approach and scale. In its assumptions, the project combines the traditional fleeting achitecture of Santorini with contemporary design. The edges inside the building and outside were rounded in a traditional manner so as to produce an impression that the actual size of the building is smaller and its visual ex-

II. 10. The Architect's House, fot. autor / The Architect's House, photo by the auther

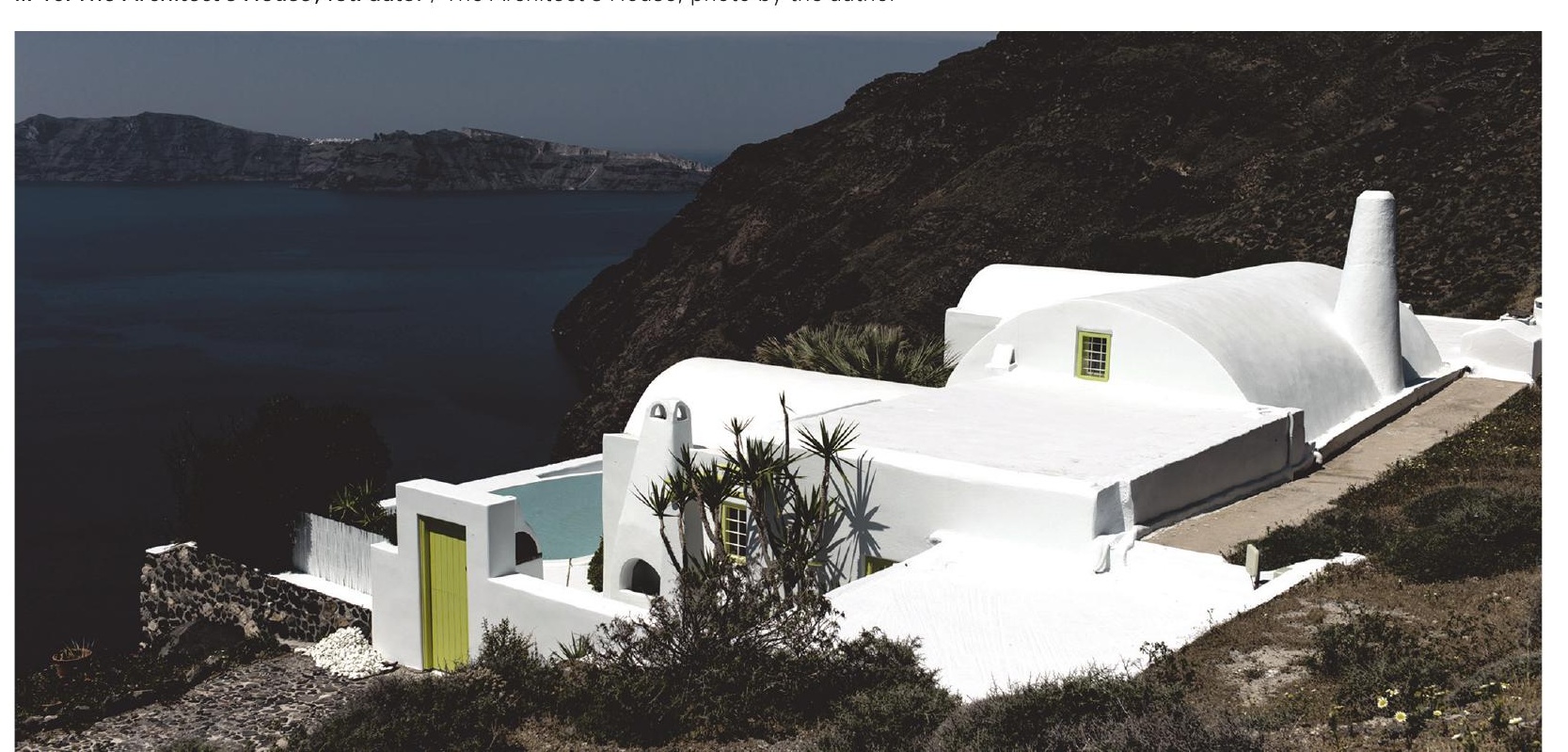



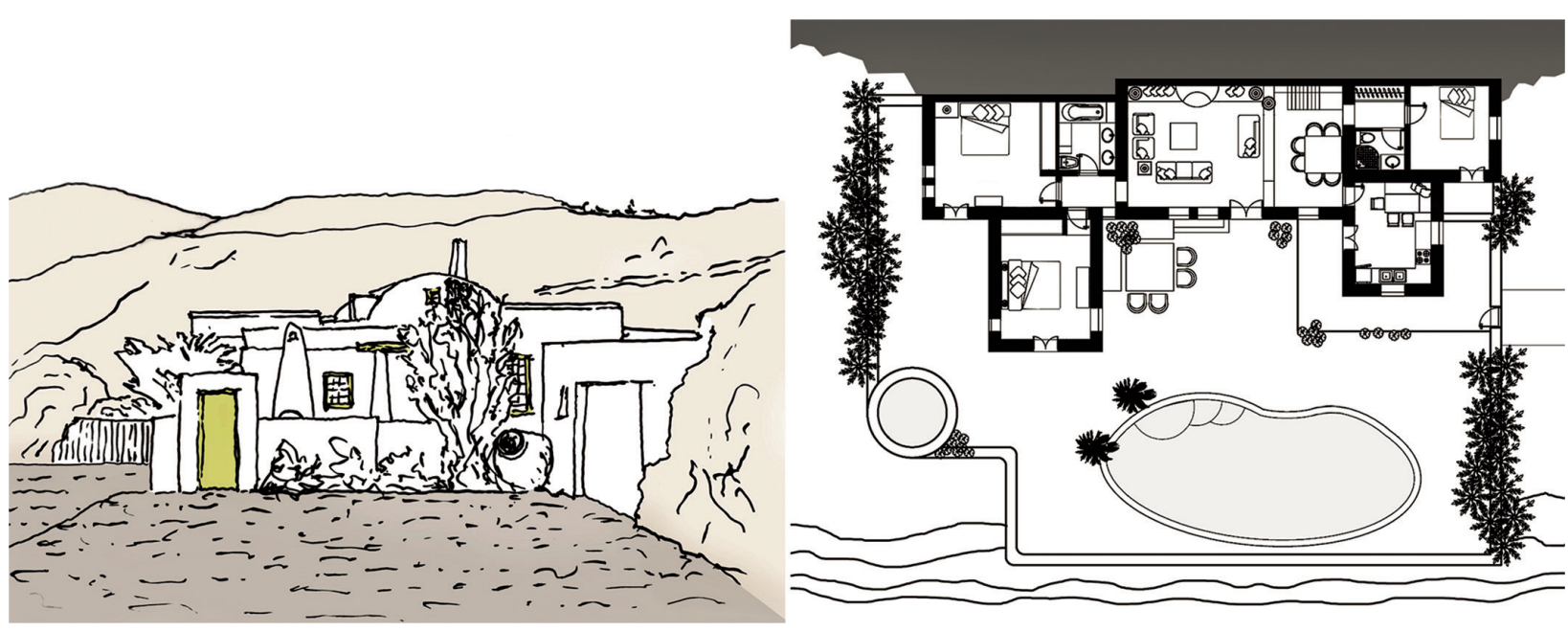

II. 11. The Architect's House,
the author and Nikos Tsebelis

budynku i na zewnątrz zostały zaokrąglone $w$ tradycyjny sposób by stworzyć wrażenie, że rzeczywista wielkosś budynku jest mniejsza a jego plastyczność i ruch (jak gdyby organicznej formy) sprawiaja, że płynie przez przestrzeń i czas. Jak rzeźba wyłania się popr

styczna energię i wieczne piękno Santorynu'13. Podsaw tektury Cyklad. Mino, ze ten kolor jest tu używany pow przestrzeni budynk Inne kolory staty sie nej i ruch które podkreślio elementy architektury, droge, deta. Zastosowanie takiego ro

Zastosowanie naturalnych materiałów, ciepłej palety kolorów, eleganckich mebli z odniesieniami do trady cyinych elementów oraz odrobina wielokulturowości w projekcie stworzyło szczególną atmosfere w środku i na zewnątrz tego jednorodzinnego dom

Budynek został niedawno odnowiony i otrzymał kolejne życie. Stał się elegancką willą wakacyjną na wynajem. Pomimo upływu czasu, budynek wciąż jest nowoczesna, białą rzeźbą na tle czarnego klifu z widokiem na wulkan i morze Egejskie.

Innym przykładem architektury nowoczesnej na Santorynie jest Aenaon Villas - zespół 7 willi hotelowych zrealizowany w 2009 roku projektu Giorgosa Alexiou ${ }^{14}$.

II. 12. Aenaon Villas, fot. autor / Aenaon Villas, photo by the author

pression and motion (as if that of an organic form) cause to flow through space and time. As if a sculpture, it in

fle clean white being commonly used here, it characterises the variety of function and the motion within the space of the building. Other colours became a tool used to highlight architectural elements, the road and various details. This solution gave the building its own identity and character The use of natural materials, a warm colour palette, elegant furniture with references to traditional elements and a dash of multi-culturalism in the design have created a unique atmosphere both inside and outside this single-family house

The building has recently been renovated and received a second life. It has become an elegant holiday villa for rent. Despite the passage of time, the building is still a modern white sculpture against the background of a black cliff, with Another example of modern architecture on

政 2009 and designed by Giorgos Alexiou 14

of Santorini. Their placement has enabled the desig to be made in such a way as to provide each buildin
Wille znalazły się w najwęższej i jednocześnie najwyż kie rozwiązanie projeku, by kazidy z buc ( Archomiany widok na kaldere i morze Egejskie. Architekt podkreśla iż najważniejszą cechą jego projektu jest znalezienie harmonii tradycyjnej zabudowy inowoczesnej architektury z krajobrazem. Budynek przy cye roz wązania zwykle stosowane w architekDo Cyklad. To luki i zaokrąglenia oraz kolor biały. Dodatkowo, architekt okiełznał wystające skały, które przenikają się przez płaszczyzny tarasów i basenów. Biel kontrastuje z czarnymi skałami a całość tworzy unikatowe wnętrza i patia. Niejednokrotnie skały występuja row wocześne we whętzach budowi. Widz odnosi wrażenie, że przebywa otoczony naturą nieZatożenie projektowe staje sie niezwykle rzźbiach.

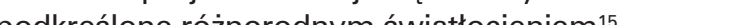

Ar wille zaprojektowat wo kajacy w nich goście hotelowi mogli napa mieszwspaniałym widokiem jednoczénie nie bedac za-

Każda z willi ma różnorodny układ pomieszczeń i ukształtowanie formy. Każda wygląda inaczej a mieszkający w nich goście utożsamiają sie z przestrzeniami w których zamieszkali. Jasne wnetrza $w$ połączeniu z nowoczesnym wyposażeniem zachowują elegancką i prostą estetykę przestrzeni. Dominuje kolor biały. Ściany, sufity, podłogi i elementy mebli pomalowane są w kolorze białym i kontrastuja $z$ kilkoma akcentami surowych stołów drewnianych i rzeźbami. Zaprojektowane są indywidualnie z dobranymi również indywidualnie elementami wnętrza. Meble, podłogi, rzezby są inne w kazdej willi'í. Oba przykłady wywodzą się z zabudowań budowanych przez mniej zamożą spolecznośc Santorynu. $\mathrm{Nie}$ są to jedyne proby realizacji architektury nowoczesnej, kore wplecione w kontekst i charakte Santorynu tworzą wyjątkowe przestrzenie, elegancję wprowadzają ponadczasowość with an unforgettable view of the caldera and Aegean Sea. that the most important characteristic of this design is the harmony between traditional building, modern architecture and the landscape. The building incorporates solutions typically found in the architecture of the Cyclades. These include arches, rounded corners and the colour white. In addition, the architect tamed the site's jag ged rocks, which intersect with the surfaces of the terraces the pols. The colour whic contasts with the black rocks, een used in the interiors of buildings quite often. Observers an $\mathrm{c}$ an impression they are suroule gardless of whether they are inside or out on a terrace. The esign is highly sculptural and is highlighted by varied plays of light and shadow ${ }^{15}$.

The architect studied the placement of each building in depth. He designed the villas so that the hotel guests residing inside could enjoy the remarkable view whilst remaining unseen themselves.

Each of the villas has a varied room layout and form. They all look different and their residents identify with the spaces in which they stay. The bright interiors, combined with modern furnishings, maintain an elegant and simple aesthetic of space. The colour white is predominant. The walls, ceilings, loors and elements of the furniture are all painted white and contrast with a number of accents in the form of raw timber tables and sculptures. They have been individually designed, each featuring unique interior elements. The fu the,

he less affent section of Santorini's community. They are the not the only attempts at building modern architey are that is incorporated into the context and character of Sanorini, creating exceptional spaces, elegance and introducing timelessness ${ }^{17}$.

5. Santorini, an island of modern architecture

When one anaylses the architecture that can be found on the island, one can observe that the best solutions take straight out of the history of this place are not the result of the desire to copy old ideas, but of rationalism. Many of the examples are also noble in their expression and as simple
II. 13. Aenaon Villas, jedna z siedmiu willi, fot. autor / Aenaon Villas, one of the seven villas, photo by the author

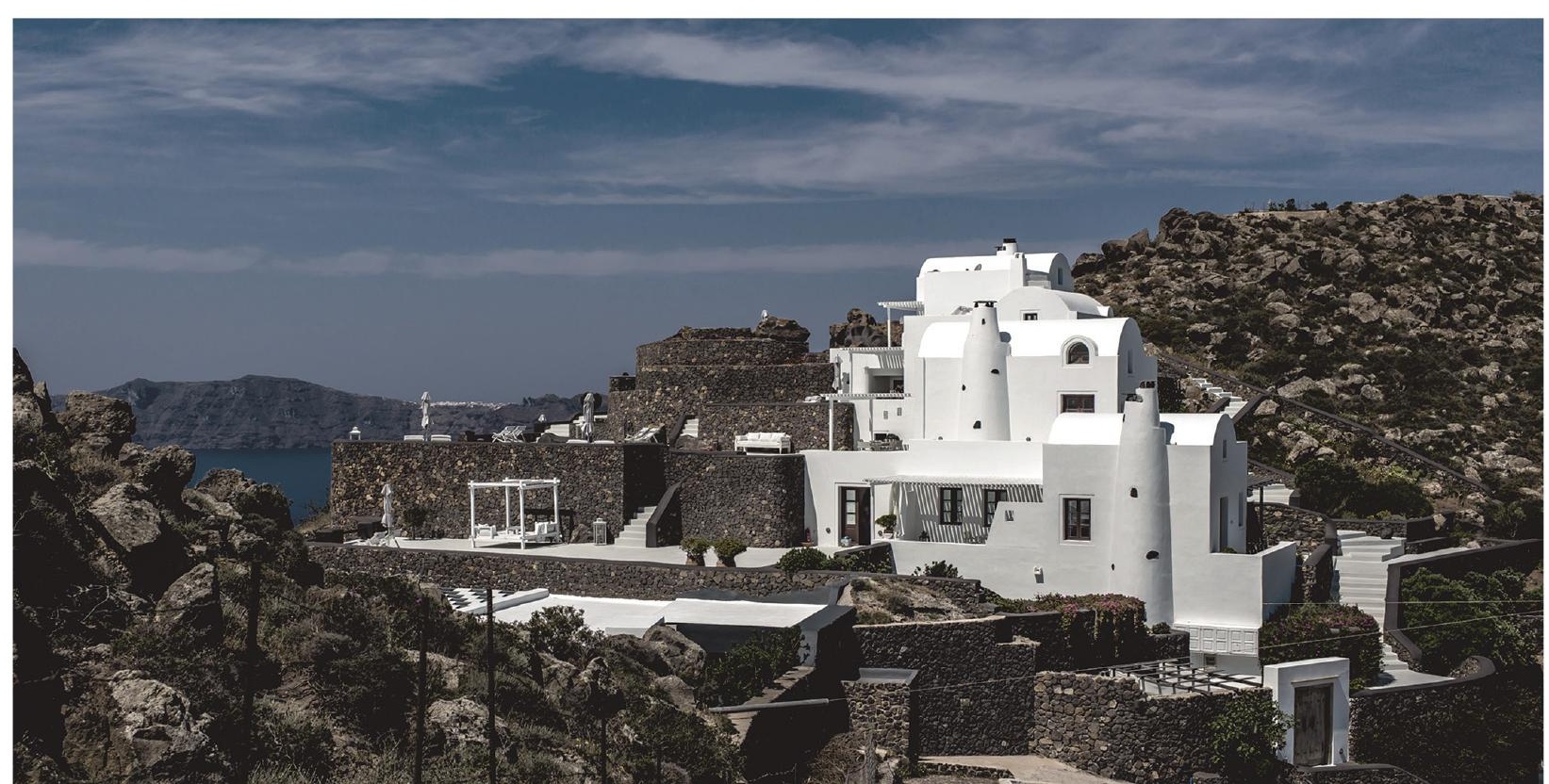




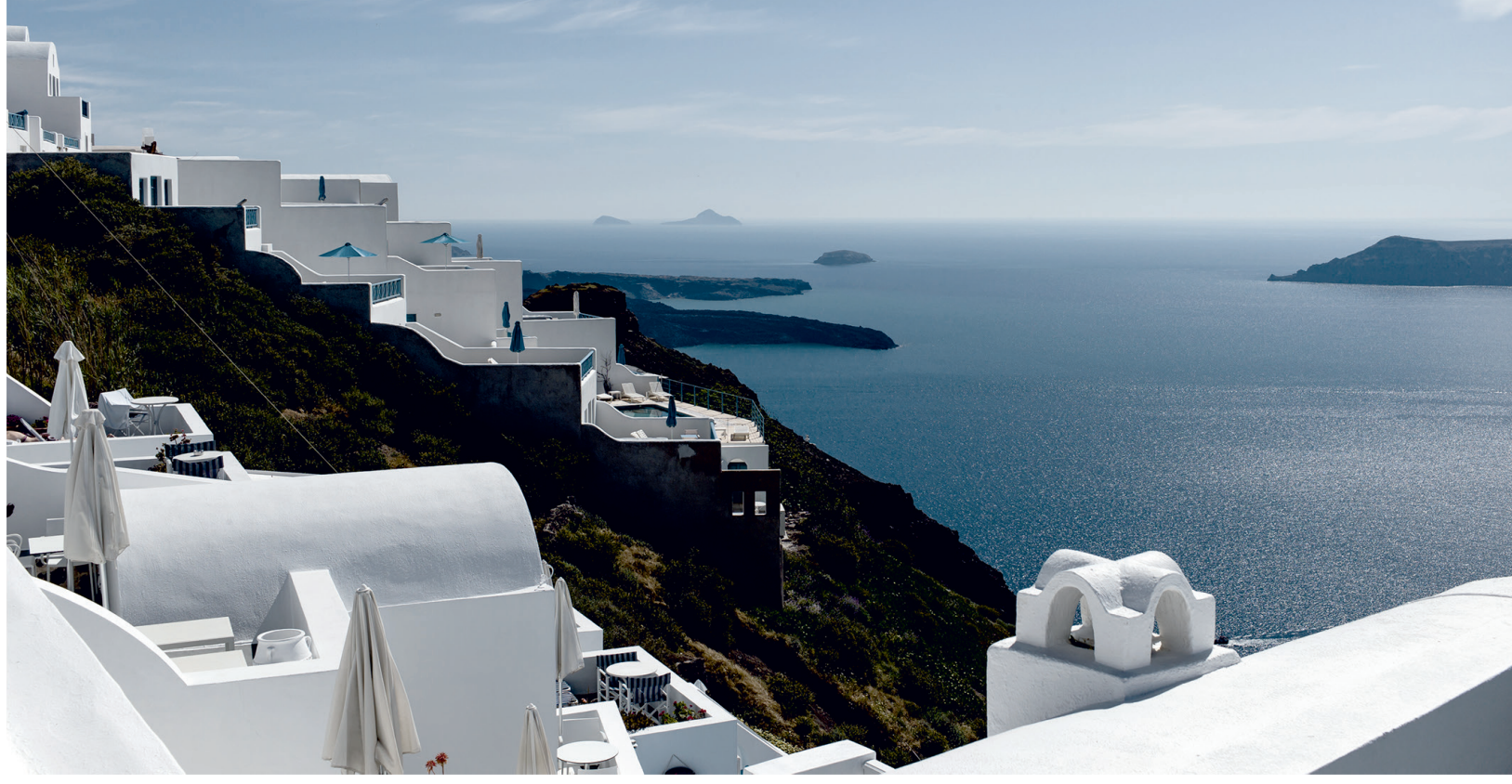

II. 14. Architektura Santorynu, fot. autor / The architecture of Santorini, photo by the author

5. Santoryn, wyspa architektury nowoczesnej

Analizując architekturę odnalezioną na wyspie możn zauwazyc, ze najlepsze rozwiązania wyjęte wprost $\mathrm{z}$ historii miejsca nie wynikają tu z chęci kopiowania starych pomystow a z racjonalizmu. Wiele z przykładow jest dodatkowo szlachetna w wyrazie, prosta jak w najlepszych rozwiązaniach minimalistów. Czy połączenie architektury zapożyczonej z kontekstu z jej racjonalnością i z naj prostszymi rozwiazaniamijest architektuą nowoczesną? Udaje sie jej uniknać zaszufladkowania do jednego stylu, nie jest archick za moder. Nistyczą, nie szuka klaSantorynu respektuje stadycje i ączy ja z nowhekura Santornitem raje Santorynu jest prostota i ponadczasowość, adaptacja do lokalnych warunków kulturowych i klimatycznych To nie moda ale twórczy proces, który prowadzi do radykalnej estetyki, szczerości użytych materiatów i unikatowych form architektonicznych Przy takich założeniach i sposobi

myślenia staje się nawa ale architekturą ponadczasowạ.

PRZYPISY

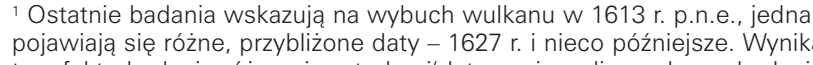
pumeksegrowe, badania

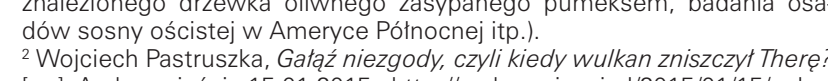

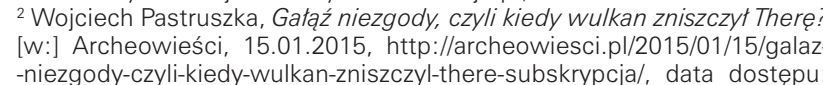
-niezgody-czyli-kiedy-wulkan-zniszczyl-there-subskrypcjal, data dostępu
29.01 .2017 r. 3 Barbara J. Sivertsen, The Parting of the Sea: How Volcanoes, Earth-
quakes, and Plagues Shaped the Exodus Story, Princeton University, 2009

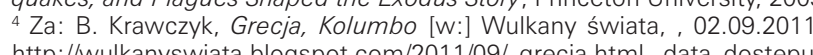

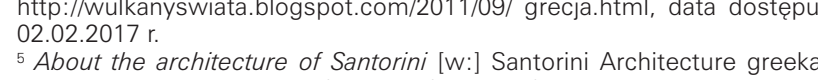
${ }^{5}$ About the architecture of Santorini/W: S Santorini Architecture greeka
com, www.greeka.com/cyclades/santorini/santorini-architecture. htm. com, www. greeka.cor
datad dotepu: 23.09 .2016
6 Aris Konstantinidis, The

nal, 1992 r. ? Giovanni Reale,
lin $1994, \mathrm{~s} .173$ as the best minimalist designs. Can a combination of 作 ty and the simplest solutions be considered modern for fined to a single style, as it is noid modemist architecture, por does it pursue Classica Reviva or ollor styles. The min it with moden design. The most importan qualities of Santorini's architecture are its simplicity and timelessness, as well as its adaptation to local cultural and climate conditions. This is not fashion, but a creative process, which leads to a radical aesthetic, the genuineness of materials and unique architectural forms. With the assumptions and manner of thinking as those described above, it becomes not only modern, but timeless.

ENDNOTES

The latest studies point to the volcano's eruption taking place in
1613 BCE, although other similar dates have been proposed, e.g. fom different dating methods (radiocarbon dating, the study of
froter Colorado bristlecone pine residues in North America, etc)

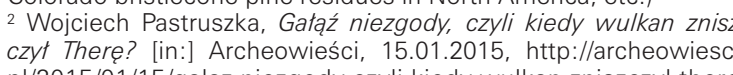

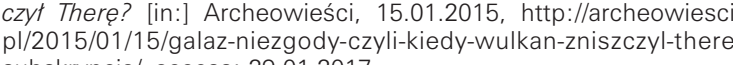
subskrypcial, access: 29.01 .2017

3 Barbara J. Sivertsen, The Parting of the Sea: How Volcanoes,
Earthquakes, and Plagues Shaped the Exodus Story, Princeton University, 2009 .
From. Brawczyk, Grecja, Kolumbo [in:] Wulkany świata, 4From: B. Krawczyk, Grecia, Kolumbo lin:I Wulkany swiata,
02.09.2011, http://wwilkanyswiata.blogspot.com/2011/09/ grecja. html, access: 02.02 .2017 of Santorini lin:] Santorini Architecture
About the architecture of
greeka.com, www.greeka.com/cyclades/santorini/santorini-archiecture.htm, accessed: 23.09 .2016
Aris Konstantinidisis, The architecture of architecture - Notes from

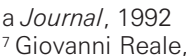

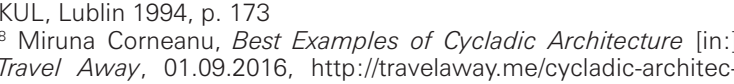
turel, accessed: 23.09.2016

Strum: Ture of Life [in: 1 G Glil, Santorini's Architecture Defined by the

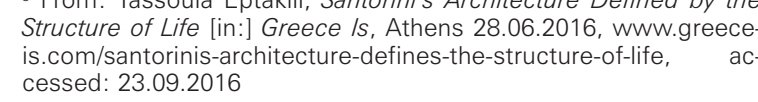

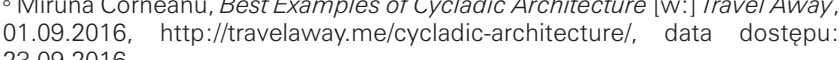
23.09. 2016
Za: Tassoula Eptakili, Santorini's Architecture Defined by the Structure of

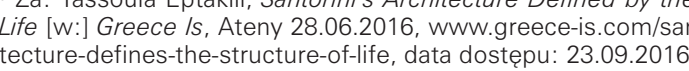

10 Il bidem

${ }^{2}$ Nikos Tsebelis, Architect's House [w:] Architects Villas, wnw.architects-

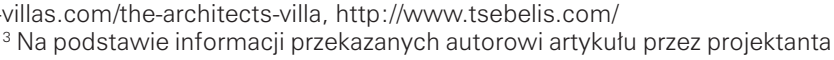
budynku Nikosa Tsebelisa, 11.10 .2016
${ }^{4} A$ enaon Villas [w: Wwww. aenaonvillas

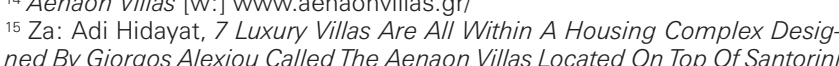
Wed By Girgosolilexiou Called The Aenaon Villas Located On Top Of Santorin -plans.blogspot.com/2014/00/7/-luxury-villas-are-all-within-housing.html do Za: Stathis Kalogeropoulos, Aenaon Villas in Santorini [w:] Design Sto-
ries, httr://mydesignstories.com/aenaon-villas-in-santorinil, data dosteppu:
1811.2016 r. "Można zwrócić uwage równiez na inne przykłady, np.: dom dwurodzinny proj. Kapsimalis Architects, 2016 r., hotel Andronikos w Imerovigli, proj. KLab Architecture, $2016 \mathrm{r}$... Hotel Grace Santorini w Imerovigli, proj. Divercity
Architects i mplusm Architects, 2010 r., The House of the Winds w Akrotiri,

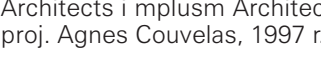

LITERATURA

[1] About the architecture of Santorini [W:] Santorini Architecture greeka.
com, www.greeka.com/cyclades/santorini/santorini-architecture.htm, data dostepu: 23.09.2016

22] Corneanu, M., Best Examples of Cycladic Architecture [w:] Travel Away, 23.09.2016,

[3] Eptakili, T., Santorini's Architecture Defined by the Structure of Life [w:]
Greece Is, Ateny 28.06.2016, www greece-is.com/santorinis-architectureGreece Is, Ateny 28.06 .2016 , www.greece-1s.com/sat
-defines-the-structure-ofl-life, data dostepu: 23.09 .2016

[4] Hidayat, A., 7 Luxury Villas Are All Within A Housing Complex Designed

By Giorgos Alexiou Called The Aenaon Villas Located On Top Of Santorin [W:I Minimalist House Design, 15.09.2014, http://house-minimalist-design(5) Ko nal, 1992 r.

[6] Krawczyk, B., Grecja, Kolumbo [W:] Wulkany świata, 02.09.2011,
http://wulkanyswiata.blogspot.com/2011/09/ grecia.html, data dosteppu [7] Pastruszka, W. Gataż niezgody, czyli kiedy wulkan zniszczyy Therę? [w:] Ar-

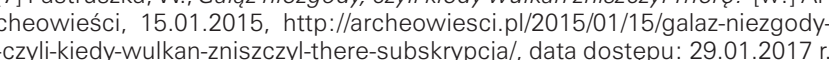
[8] Reale, G., Historia filozoffii staroziytnej, .T. 1, Wydawnictwo KUL, Lublin [19] 4 ivertsen, B. J. The Parting of the Sea: How Volcanoess, Earthquakes, and
Plagues Shaped the Exodus Story, Princeton University, 2009 (1) Stathis Kalogeropoulos, S., Aenaon Villas in Santorini [W:: Design Sto 18.11.2016 r. [11] Tsebelis, N. Architect's House [w:] Architects Villas, www.architects-
${ }_{11}^{10} 1 \mathrm{lbidem}$ /bidem.

${ }^{2}$ Nikos Tsebelis, Architect's House [in:] Architects Villas, www
architects-villas.com/the-architects-villa, http://www.tsebelis com/
13 Based on information shared by Nikos Tsebelis, the author of
the design, with the author of the article, 11.10.2016

${ }^{15}$ From: Adi Hidayat, 7 Luxury Villas Are All Within A Housing Complex Designed By Giorgos Alexiou Called the Aenaon Vilitlas Located On Top Of Santorini [in:] Minimalist House Design,
15.09.2014, http://house--minimalist-design-plans.blogspot

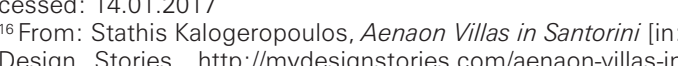
santorini/, accessed: 18.11.2016

tesigned by Kapsimalis Axchamples 'two-family'n Profitis llias, Messaria, designed by Kapsimalis Architects, 2016, Andron kos Hotel in Imerovigli, desinged by KLab Architecture, 2016 ects and mplusm Architects, 2010, The House of the Winds in

BIBLIOGRAPHY

11) About the architecture of Santorini [in:] Santorini Architec-
lure greeka.com, whw greeka. com/cyclades/santorinisantoni-architecture.htm, accessed: 23.09 .2016

Travel Away, 01.09.2016, http: of /travelaway Melcyitecture lin tecture/, accessed: 23.09.2016

BJ Eptakili, T., Santorin's A Architecture Defined by the Structure santorinis-architecture-defines-the-structure-of-life accescessed

23.09. 2016
4] Hidayat, A. 7 Luxurn Villas Are All Within A Housing Complex
Designed By Giorgos Alexiou Called The Aenaon Villas Located On Top Of Santorini [in:] Minimalist House Design, 15.09.2014

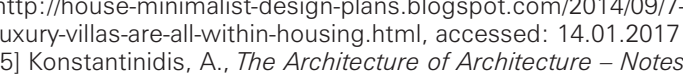

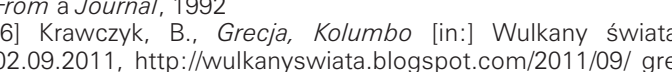
cja.html, accessed: 02.02.2017 esci.pl/2015/01/15/galaz-niezgody-czyli-kiedy-wulkan-zniszczy-

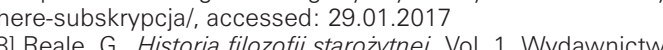
KUL, Lublin 1994 . The Parting of the Sea: How Volcanoes,
(9) Sivertsen, B. J., The Pros Story. Princeto Earthquakes, and Plagues Shaped the Exodus Story, Princeto
University. 2009

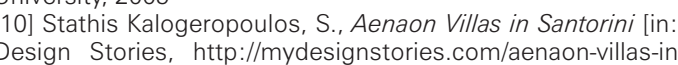
santorinil, accessed: 18.11.2016

[111] Tsebelis, N., Architect's House lin:] Architects Villas, wnw.ar 